\title{
The Political Development of Contemporary China from the Perspective of Historical Political Science
}

\section{Guangbin Yang ${ }^{1}$}

Received: 13 August 2021 / Accepted: 19 August 2021 / Published online: 4 September 2021

(C) The Author(s) 2021

\begin{abstract}
The political development of contemporary China defies existing political theories. The framework of "political science" based on the 'rational man hypothesis' has proven to be fallible in terms of correctly envisioning China's future. Appertaining to the Chinese political history, historical political science offers not only epistemology and methodology of the subject, but also an ontological element, for observation. With respect to historical political science, contemporary Chinese politics is considered to be the natural genetic extension of the Chinese civilization as well as a continuous and unified development process spanning over a period of 70 years ever since the People's Republic of China was founded. Historical political science, deemed to be a tailored research approach for the development of contemporary Chinese politics, essentially adds further value and significance to this discipline.
\end{abstract}

Keywords The genetic community of Chinese civilization - Historical continuity · Historical political science $\cdot$ Political development of contemporary China

This article is a review of how the political development of contemporary China appears as a major agenda in both, Chinese and foreign political sciences, as well as a substantial challenge to the existing political theories. Since the founding of the People's Republic of China (PRC) over 70 years ago, the West has been assessing China's prospects by virtue of their own ideas and set paradigms, but were all proven wrong (Huang and Huang 2013). The apparent reason behind this outlook is that the Western press and academia strongly endorse the dichotomy of "democracy and non-democracy", and believe that any political path or system that does not conform to the Western democratic ideology is certain to encounter problems sooner or later and even lead to the failure of the state, along with the inevitable "democratic transition". In that sense, Westerners have long been convinced of the "end

Guangbin Yang

yanggw@ ruc.edu.cn

1 Distinguished Professor of Political Science and Dean of School of International Studies at Renmin, University of China, Beijing 100872, China 
of history", and Fukuyama proclaims it publicly (Fukuyama 1992). Global political realities such as the evolution of the "Arab Spring" into the "Arab Winter" and the "democratic resurgence" realized by many countries challenged the "common view" originated from the dualistic world view. For that reason, numerous pragmatic Western political scientists have called for an "end to the transition paradigm" (Carothers 2015), i.e., to stop assessing global politics through the prism of the dichotomy-based "democratic transition". However, it is difficult for Western scholars to cease this practice because the capitalist or market society in which they reside is essentially the product of self-interested individualism, which makes it impossible for them to avoid using individualism as a measure of all political relations. Hence, Western social science is primarily based on Hobbes "rational man" hypothesis (Hobbes 1688/1994). According to Hobbes, man is the most elementary component of a country. Understanding a country first requires understanding "human nature"; and when that is comprehended, everything else becomes comprehensible. The scientific analysis of human nature describes man as rational and self-interested; hence "political science" is predominantly predicated on the hypothesis of rational man.

Hobbes' "political science" not only deviates from the classical political traditions adopted by various Western countries, but also bears no relation to the political traditions of several other non-Western countries. If the understanding of human nature makes politics a science, then it does not justify the various irrational political catastrophes brought about by human beings who are in favor of science. The rational man hypothesis can illustrate, to a certain extent, the economic life in which individuals are the subject, but fails to explain the political life in which groups become the subject. The sum of individual rationalities is not equal to the rationality of the group. That is why there exist events such as the genocide of American Indians by the white settlers, the election victory of Mussolini and Hitler, and the referendum supporting the UK's Brexit. "Political science" that stems from the hypothesis of rational man can neither explain the multiple political misfortunes experienced by humanity till date, nor can it direct humanity's future. In the theory of international relations, the realist hypothesis of "anarchy" is deemed to be derived from Hobbes' "state of nature", but realist theorists disagree with his postulation of "rational man". According to Waltz, "If man is a completely rational animal, he will always act in accordance with the absolute precepts. But he is not. Conflict and violence arise from the secular nature of man". "The behaviors of bees and otters, which are dominated by their instincts, show regular patterns and predictable results. On the other hand, citizens of a purely rational world will act according to pre-made plans. Since human behavior does not belong to either of these two categories, the 'systematic human history' seems impossible." (Waltz 2008: 4, 8).

The 'rational man hypothesis' based political science tends to completely abandon history. After World War II, in particular, waves of behavioralism and rational choice theories became widely popular, "scientization" was intensified, and quantitative research based upon this hypothesis became an elusive game of symbols that was completely unrelated to the real key issues. By and large, political studies were not really about political realities of the time.

Against this backdrop, Habermas tracks the origins. If Aristotle represents contextuality, i.e., historicity, of practice under the classical political view, Hobbes is a 
representative of the modern political view-whose first principle is non-historicity. Hobbes' claim is that "scientifically grounded social philosophy aims at establishing, once and for all, the conditions for the correct order of the state and society as such. Its assertions are valid independently of place, time, and circumstances, and permit an enduring foundation for communal life, regardless of the historical situation" (Habermas 1973). Habermas contends that social philosophy, even though originating from history, has renounced history; and social science originates from classical politics, but has evidently deviated from classical politics. Therefore, historical traditions remain essential for the suitable development of social science. According to Habermas, social science represents the unification of history, theory, and practice; and does not merely deal with the relationship between theory and reality.

History is regarded as a "religion" for the Chinese people. With such a long and rich history of civilization, the Chinese people possess a tendency to be nearly innate historians. Hence, it seems only natural for them to "look at issues from a historical perspective", and the political view based on the perspective of historical political science therefore appears to be quite different from that of the rational man hypothesis. Therefore, what is historical political science? In addition, from the perspective of historical political science, what is the relationship between China's political development before and after the reform? What is the relationship between the political development of the PRC and the history of China? What does historical political science mean for the indigenous knowledge system? These are some of the major issues that this article tries to address.

\section{What is Historical Political Science?}

Before discussing this proposition, we first need to answer this question: why do we need historical political science? China abolished political science as an independent discipline in the 1950 s, but scientific socialism, one of the three major principles, actually belongs to Marxist political theories. After the reform and openingup, political science was resumed in China and was basically deemed equivalent to scientific socialism, focusing primarily on the theories concerning class, state, government, party, revolution, nation, etc. Objectively speaking, these topics undoubtedly remain evergreen and will never be outdated, but they also need to evolve with the changing times. During the early 1980s, Western political science, particularly political science in the US, began to be introduced in China extensively. American political science was sort of a "revolution" against the political science in Europe: conceptually, it shifted from "high politics", which covered areas such as state and constitution, to "low politics", which encompassed society, interest groups, and even relevant individuals; methodologically, it established the non-historical structural functionalism to evaluate the political modernization in various cultures and regions, attaining the highest level of non-historicity (Almond and Coleman 1960). In the 1970s, Rational choice theories had replaced the declining structural functionalism, a more non-historical belief based on rational man hypothesis began to dominate the main political science. When the non-historical methodology encountered 
the "third wave of democratization", it became inevitable for rational self-interested people to pursue democratization, thereby causing the popularity of the "transition paradigm". In this context, scholars who opted for historical thinking seemed to lose their faith and began pursuing liberal democracy as a "universal value", which signifies unconditional feasibility and applicability.

The value of theory and methodology lies in their power of elucidating real politics. The crises both in Western countries and non-Western transition countries had proven to be gravely detrimental for the non-historical modernization and democratization theories. Liberal politics needs to find a solution while American politics demands "bringing history back". ${ }^{1}$ In Why and How History Matters, Charles Tilly, a famous historical sociologist, claimed that it would be highly problematic for interpretive political science to make any progress without undertaking careful historical analysis, since history is filled with a number of critical political phenomena, and political interpretation must be conducted in accordance with history (Tilly 2006).In fact, as early as the 1980s, historical institutionalism emerged as an opposition to the mainstream rational choice theories, with the latter being an approach that dealt only with institutions and did not involve history (Eckstein 1998). At the same time, the Western theoretical systems and research methods evidently failed at explaining the unique development path and mode in China, which stemmed from the wisdom incorporated from historical practice and institutional autonomy. New methodologies were required to effectively describe the Chinese model. With such a long and rich history and profound historical political science integrated in the road and the mode in China, it is firmly believed that the Chinese people do not require an external political interpretation for their development.

Now, what exactly is meant by historical political science? In a way, historical political science, an integral part of historical sociology, is a historical social science in itself. Historical sociology entails the study of politics, economy, and culture, i.e., the "total society" seen from the perspective of history and for achieving theoretical findings; or for applying existing theories in a historical context, to test their authenticity. Historical sociology is a field that deals with the discovery and testing of theories. Historical political science is quite closely related to historical sociology, but principally, as an approach in the Chinese context, it possesses a specific scope and characteristics. The significance of historical sociology is primarily reflected in the approach or methodology, and to begin with, historical political science is quite pivotal ontologically, as well as epistemologically and methodologically. That remains the fundamental reason for the proposal of historical political science under the condition of mature and developed historical sociology. Fortunately, China's political circle has achieved results in line with the similar approach of historical political

\footnotetext{
1 In 2000, an email sent by Mr. Perestroika criticizing the excessive scientization of the American Political Science Review raised great concern in the American political science community, which began to pay attention to the role of history. Some used history as background information to enrich their quantitative research, and some proposed the "historical turn", as in Giovanni Capoccia and Daniel Ziblatt's The Historical Turn in Democratization Studies (Comparative Political Studies, Vol. 43, No. 8/9, 2010). However, the research environment in the United States determines that "history" can hardly become an agenda for normal scientists in American political science.
} 
science, such as the idea of "rights from ancestors" proposed by Professor Xu Yong and rural investigations from the perspective of historical continuity (Xu 2018a, b). An academic community is required for research based on historical political science. But before that, we should first try to comprehend the essence of historical political science.

\subsection{Historical Political Science as Ontology}

"History" in historical political science is ontological in nature. Compared to the history of other countries, the history of China, above all, is the history of politics, which includes political thoughts, political institutions, and dynasties. The "political nature" of Chinese history is unparalleled. Therefore, how should we understand the Chinese history as political history? According to Kozo Mizoguchi, the famous Japanese expert on Chinese issues, China possesses its own historical reality and development, which is very clearly reflected in the slow and constant changes occurring in various phenomena taking place in different eras spread over a long period of time. Therefore, we should understand China's modernity from the relationship between its contemporary, modern, and pre-modern times. That is the "basal body of China" (Mizoguchi 2011).

It is nothing short of a miracle that China is the only civilization that has lasted for 5000 years without interruption. One cannot call Chinese civilization an "ancient civilization", since ancient civilizations are those that have either been interrupted or have died out. Therefore, what are the exceptional "genes" that support the constant institutional changes? In my opinion, the unique "genes" of Chinese civilization include the following at any rate: the Chinese nation, the fundamental unaffected Chinese characters, the territory with the Yangtze River and the Yellow River as the core, the idea of unification at the national level, the people-oriented governing philosophy, the bureaucracy at the government level (including the county system and the imperial examination system), the inclusiveness and the golden mean at the cultural level, the freedom and autonomy of social life, the focus on family ethics, and the Tianxia (world) system in foreign relations. These "genes" are internalized and instilled in the Chinese nation inhabiting in a fixed territory and form the Chinese civilized community that has spanned over thousands of years. Such a community, composed of civilization genes, is termed as the "genetic community of Chinese civilization". A civilized-genetic community is a community created by populaces inhabiting in a fixed territory, possessing constant integral civilization beliefs and lifestyle in addition to other genes, over thousands of years (Yang 2016a). On the political level, the core elements of the "genetic community of Chinese civilization" can be summarized as: the view of a unified state, the view of a people-oriented government, the benevolence-based social relationship, and a global approach to foreign relations.

The genetic community of Chinese civilization in itself is deemed a political science worth studying. That is the political significance of "history". Therefore, what does political science cover? It covers a range of issues such as a country's political values, political institutions, and political behavior (choice of interest). The genes of 
a country obtained from historical civilization may be strong or weak, but majority of the countries must be endowed with appropriate political values, political institutions, and corresponding behavior. As far as Chinese politics is concerned, the selection of values, the design of institutions, as well as the behavioral patterns are all subject to the established "genetic community of civilization", which is elaborated in Sect. 2. In the same context, "historical political science" is not only politics of the past, but also of the present. The fundamental difference between historical political science and historical sociology lies in its ontological nature.

\subsection{Historical Political Science as Epistemology}

Habermas interprets the historicity of the Aristotelian political science as contextualism, which is generally known as 'conditionalism'. When Chinese people say, "looking at the problem from a historical perspective", we in fact mean, to look at the conditions in which the problem arises. That is historical political science in the epistemological sense. Aristotle came up with the three best constitutions, three perverted constitutions, and various "sub-constitutions" based on the population structure, industrial changes, and class composition. He argued that the best form of government in one city-state may prove to be a bad one in another city-state. In modern times, with the formation of world politics promoted by trade, technology, and cultural exchanges, intellectuals have broadened the spectrum of political conditionalism. The 'theory of moeurs' that was popular in France and Marx's famous axiom stating "base determines superstructure" both are the continuation of Aristotle's theory of conditions. Even during the Cold War, scholarly democratic theorists, such as Robert Dahl, summed it up profoundly, "I have suggested yet again that certain underlying or background conditions in a country are favorable to the stability of democracy and where these conditions are weakly present or entirely absent, democracy is unlikely to exist, or if it does, its existence is likely to be precarious." (Dahl 1998). This is similar to a Chinese idiom stating, "the climate (soil and water) not agreeing with someone". Here, the "basic conditions" are the "soil" in reality and the "background" is "water" from historical sources, hence the idiom talks about the historical and realistic conditions. The Chinese people are quite prudent to understand the philosophy behind this idiom and use it to their benefit, while the conclusion of "the end of history" based on the rational man hypothesis suggests arrogance and ignorance, hence the countless political catastrophes.

\subsection{Historical Political Science as Methodology}

Historical continuity is the essence of historical political science in terms of methodology. Historical continuity comes across as the common sense of history, which in turn forms the common sense of life. How is it established? The answer lies in the internal mechanism of historical continuity. After the birth of historical institutionalism, people perceived historical continuity as something closely related to the historical truth, and historical analysis transpired to be more logical and even "theoretical". That is because historical institutionalism provides some concepts for 
the analysis of the causal mechanism (Yang 2016b). For starters, it offers the concept of "sequence", which is composed of "timing" and "critical juncture". In the sense of timeliness, the earlier a key event occurs, more profoundly it influences the subsequent institutional changes, like the thoughts and institutions established in the Axial Age determining the path for future thoughts and institutions. Second, the reason is that a key event occurring at an earlier time would become an institutional arrangement, and through self-reinforcing, the result would increase the returns. In the end, it would transpire into something on which the path depends and could even fixate the path. Thirdly, historical continuity is not only a part of gradual institutional changes. Even with the abrupt changes in institutions, such as revolutions and reforms, it gets difficult to exclude institutions, thoughts, and even behavior by virtue of "the genetic community". These have been validated by a large number of comparative historical studies and are also accepted as common wisdom.

Historical political science in terms of ontology, epistemology, and methodology is undoubtedly a novel approach to understand in general how rational and legitimate China's political development is. It can also be implemented to theoretically describe the historical continuity before and after the reform since the founding of the PRC.

\section{The Political Development of Contemporary China as the Continuation of the Basal Body of Chinese Civilization}

The past century has witnessed tremendous changes in China's political and social forms, but the people did not sever the country's historical bloodlines and genes. Despite the institutional mutations, China's 5000-year-old history of civilization remains intact. What General Secretary Xi Jinping mentions below are the ideological propositions or chief political agendas that require in-depth study. ${ }^{2} \mathrm{Mr}$. Xi suggested that "in promoting and interpreting the Chinese characteristics, we should make it clear that each country and nation has their own historical traditions, cultural legacies, and basic conditions, and their development path must have their own characteristics; that the Chinese culture contains the greatest spiritual pursuit of the Chinese nation and continuously nurtures the Chinese nation for its growth and prosperity; that the outstanding traditional Chinese culture constitutes an outstanding advantage of the Chinese nation and our strongest soft power; and that socialism

\footnotetext{
2 In every country, the official proposition is a political agenda worthy of attention and research, because there is a powerful ruling group behind it. The official proposition either reflects the wisdom of the ruling group or the questions that need to be answered or resolved by it. Therefore, social science should not stay away from the "official" on the grounds that it is a part of academic research only. It must be realized that social science is essentially policy science because social science is the science of answering major practical questions, and official propositions are often the most important practical questions. Regarding the major real agendas, either criticism based on idealism or defense based on realism can be adopted, but both should be constructive, not negative. American politics after World War II, in fact, entails studies of the Cold War, which is about the defensive theory. Chinese social science, especially political science, should not deviate from the defensive theory.
} 
with Chinese characteristics, which is rooted in the fertile soil of the Chinese culture, reflects the wishes of the Chinese people and meets the demand for the development and progress of China and the times, has a profound historical origin and a broad practical basis" (Xi 2014). He also expressed that "a country's choice of governance system is determined by its historical heritage, cultural traditions, and the level of economic and social development. It is determined by the people of the country. Today, China's national governance system is the result of long-term development, gradual improvement, and endogenic evolution on the basis of China's historical heritage, cultural traditions, and economic and social development" (Xi 2014).

These propositions and agendas can be evaluated and understood from various perceptions, especially from that of historical analysis. We believe that historical political science is a more appropriate perspective and approach. China's current development path and institutions and the modernization of national governance that it is engaged in represent the political sections and emerge as a natural continuation of the basal body of Chinese civilization. This is clearly reflected in the national unity, political values, political institutions, social forms, and foreign relations of the country. The last two topics are not covered in this article as they are irrelevant to the topic.

\subsection{National Unity}

The civilization system is an integral part of the civilization carrier, i.e., the core country. Without the support of a core country, the civilization would just die out, just as multiple ancient civilizations in history did. In other words, the fate of the genetic community of Chinese civilization depends on the country of China, the cultural and educational tradition ${ }^{3}$ of "using culture to express and convey philosophy", and the entity of the state. As an entity, China must be unified historically. The history and contemplation of China's unity has provided valuable expertise and a pivotal model for world peace. As Daisaku Ikeda and Toynbee suggest, "As far as the Chinese are concerned, for thousands of years, they have been more successful than any other nation in the world in bringing together hundreds of millions of people politically and culturally. Their prowess to unite politically and culturally has proven to be an unparalleled experience. Such unity is an absolute requirement of today's world. The unity of the world is the way to avoid collective suicide of mankind. In this regard, the most fully prepared nation among all nations is the Chinese nation that has cultivated a unique way of thinking over the

\footnotetext{
3 The cultural and educational traditions in the Chinese civilization are the profoundest force to maintain the unity of China, hence, even the Manchu rulers themselves eventually were sinicized through the cultural and educational traditions. In The Emperor's Guide to Senior Ministers by Emperor Shunzhi, the first emperor of the Qing dynasty, officials are encouraged to observe the Confucian norms. (Zurong, Wang, 2019. Several Arguments on and Origins of the New Qing History, Dongfang Journal Spring Issue 3.) For that reason, it is unconventional nonsense that the New Qing History argues about the nonChineseness of the Qing dynasty based on the subject of the nation.
} 
past two thousand years." (Toynbee and Ikeda 1976) World history is a testament that unitary control generates peace while multiple control brings war and chaos.

It is widely known that after the late Qing dynasty, the national unity faced several fundamental challenges. The colonial and semi-colonial state and the political turmoil caused by the Beiyang warlords tore China apart. In fact, it is believed that when the emperor, the traditional state organizer, no longer functioned, the warlords would not guarantee national unity either. During such an event, the state needs a new organizer. In the context of comparative politics, there are known cases of the United Kingdom and the United States organized by merchant groups and Germany and Japan organized by bureaucracy. These two political forces were absent in China in the first half of the twentieth century. That is why political parties became the organizer of the country. However, due to the continuation of warlord politics in effect, the Kuomintang was unable to serve as organizer of the country due to its internal fragmentation. Thus, this historic task fell on the shoulders of the Communist Party of China (CPC). The CPC fulfilled its mission and accomplished the great task of state-building and unity on the mainland through its armed group with special political ideals. Compared to the early developed nation-states (one nation for one state), late-developing countries, such as China, are multi-ethnic communities, which encounter a trickier task of organizing the state and an even greater demand for the ability to organize or govern the state. Without the CPC, there would be no PRC; without the CPC, the idea of a unified China would be impossible. From this viewpoint, the biggest challenge that China is facing in the twenty-first century is how to maintain national unity. Without the CPC, the chances of national division are very likely (Ma 2011). The destiny of the party determines the destiny of the country as well, or the destiny of the country is tied to that of the party. That is the theoretical connotation of the state in the "leadership system of the party and the state".

Essentially, the process of CPC founding the PRC has two theoretical meanings. One is party-centrism in the context of social science: the path adopted by the UK and the US gave rise to society-centrism, the path taken by Germany and Japan created state-centrism, and the path taken by Russia and China naturally generated party-centrism (Yang 2011). The other meaning is in the sense of traditional Chinese political thought: the "leadership system of the party and the state" inferring that the CPC has become the inheritor of the orthodoxy of national unity. In his political report On the New Stage, which was delivered at the Sixth Plenary Session of the Sixth Party Central Committee, Mao Zedong said, "Today's China is a development of historical China. We are Marxist historicists, and we should not cut off history. From Confucius to Sun Yat-sen, we should summarize and inherit the precious legacy" (Mao 1991). That is why General Secretary Xi Jinping attributes a great deal of importance to the traditional Chinese culture. He has visited the Confucius Research Institute of China, spoken at the World Confucian Conference, and spoken multiple times about the significance of traditional culture. Mr. Xi regards China as a continuum of the 5000 years of civilization history and 170 years of modern history. 


\subsection{Political Values}

A country is founded on certain political values, which are also called the "fundamental values of the country". For China, its fundamental values are the core socialist values, which comprise of the value principles at the national, social, and individual levels. The core socialist values are extremely inclusive, wherein they include not only the consistent Marxist values that the CPC has been adhering to, but also certain elements from traditional Chinese culture, as well as the outstanding achievements of human civilization. They portray the ever-inclusiveness of the Chinese culture, just like the fusion of Confucianism, Buddhism, and Taoism in history, and implies that the localization of Marxism must be a process featuring the integration of the Chinese culture with the outstanding achievements of human civilization. The reason why Marxism could quickly take root in China lies in the accommodating nature of socialism and traditional Chinese political thought, especially the people-oriented thought. Socialism focuses on "society", which is essentially related to people; and the people-oriented thought, as the name suggests, also centers around people. Both, socialism and traditional Chinese political thought, are based on the people and the masses, in essence.

In fact, theorists in China and abroad have long viewed China's traditional political forms from the perspective of socialism. If liberal economics was born in China, as someone argues that the "Taoists were the world's first libertarians" (Rothbard 2006) then socialism appears to have a long history in China as well. The earliest socialism can be found in Guan Zi: Interpreting the Situation, in which Guan Zhong advocates the people-oriented thought, fairness, and selfless in governing the State of Qi. "When the ultimate political ideals are implemented, the state is for the public" - a 1000-year-old popular saying can also be regarded as the earliest simple socialist thought. Researchers in China and abroad believe that the socialist policy enabled Emperor Wu's Han dynasty to reach its heyday. Dr. Chen Huanzhang, who graduated from Columbia University and was supervised by Kang Youwei, a leading figure in the earliest and the most systematic study of socialism since modern times, argues that Sang Hongyang "made it possible for Emperor $\mathrm{Wu}$ of the Han dynasty to expand the Chinese empire without financial constraint. His contribution to the country on the whole is huge and eternal. He is the first person to successfully practice national socialism on such a huge scale" (Chen 2009). Will Durant, author of The Story of Civilization, believes that it was socialism that made China prosper. To solve the increasingly severe issues concerning people's livelihood and the economy, Emperor $\mathrm{Wu}$ implemented economic reforms. "Wu Ti [Emperor Wu] experimented with socialism by establishing national ownership of natural resources, to prevent private individuals from 'reserving for their sole use the riches of the mountains and the sea in order to gain a fortune, and from putting the lower classes into subjection to themselves'. The production of salt and iron, and the manufacture and sale of fermented drinks, were made state monopolies... Great public works were undertaken in order to provide employment for the millions whom private industry had failed to maintain...; for a time the new system flourished... China had never prospered so much before" (Durant 1963). 
Sun Yat-sen, the forerunner of the Chinese revolution, regarded himself as a socialist and the realization of socialism in China as his goal. As Mr. Sun says, "China is a solid advocate of socialism... It shows that the idea of socialism has been etched on the minds of our people. It is appropriate that socialism should proceed as fast as it can." (Sun 2011), "I really welcome socialism because it benefits the country and the people, contains the truth about society, puts everything produced into public ownership, and reaps the benefits. The day when socialism is realized, our children will have access to education, the elderly will be taken care of, and each industry will run separately and smoothly. The Republic of China will be a socialist country." (Sun 2011).At the same time, Mr. Sun acknowledged and warned that "if we don't consider how to prevent the possible rise of capitalism in the near future from the first day the Republic of China, what awaits us is a new tyranny that is a hundred times fiercer than the tyranny of the Qing dynasty" (Sun 2011). Like Mr. Sun, the early CPC members and scholars in the Republic of China also believed that China has an innate sense of socialism and that capitalism is a cruel approach.

Mr. Sun and other pioneers recognized that there are two "leviathans" in the world-one is the national or political leviathan and the other is the capital leviathan, and the harm inflicted by the latter is by no means lesser than the former. This is the world that Mr. Sun comprehended, and it is also the truth of capitalist politics in the world today. Therefore, unswervingly adhering to the socialist path and the core socialist values has emerged as a huge test for China, which is still placed in the capitalist economic system, and the Chinese model. If China, like other developing countries, integrated into the capitalist economic system and became a part of it, its fate would never be anything better than the other developing countries.

\subsection{Political Institutions}

If political values, which are considered as the fundamental values of the country, are related to the direction of a country and the mental state of a nation, political institutions, which embody the political values, become organizational principles and structures in the political value system, which are accomplished through the organization of a country. The widely known "Four Great Inventions" are related to technologies or instruments. China's greatest invention should be the earliest establishment of a bureaucratic or administrative system that unites mankind. Westerners regard the emergence of nation-states and the bureaucracy of organizing nation-states in the fifteenth to seventeenth centuries as a major sign of "modernity". From that perspective, the states, politics, and administration of the pre-Qin period were inherently modern. Not only did they have the bureaucracy and the prefecture-county system based on which a state was organized, but the systems implemented were based on performance rather than kinship. As Weber sees it, the military and the bureaucracy are the foundations of European feudal countries (Weber 1921/1978), while the countries in China's history primarily functioned based on their cultural and educational traditions as well as the bureaucracy, which act as the 
carrier of those traditions. Values and institutions were highly unified, which could be attributed to the country's scholar-officials' tradition.

Currently, the organizational principle of the leadership system of the party and the state is considered democratic centralism. "Democracy" refers to the rights of the masses, and this is a new system introduced by the CPC into the revolution. Institutional systems established in accordance with the principle of democratic centralism, such as the discipline inspection and supervision system or the organization and personnel system in the leadership system of the party and the state, can be traced back to the "Six Ministries" in ancient China. As a scholar revealed, "The Organization Department and the Disciplinary Committee are absent in the Western political system, but they are critical for China's political system as these two organs deal with the promotion and supervision of officials, respectively. These also originate from the profound historical and cultural traditions of China, inheriting and transforming the Ministry of Official Personnel Affairs and the supervisory censorship system in feudal China." (Xie 2019).

More importantly, China's administrative system appears to be impersonal, hierarchical, and performance-oriented, which are the basic organizational features defined in Max Weber's bureaucracy theory. The values are also deeply integrated with it. Both party and administrative organizations regard the practice of core socialist values as an indispensable part of administrative work and administrative procedures. For example, it is the responsibility of governments at all levels to eradicate poverty and guarantee social justice; and the rule of law and democratic procedures must be transparent, which should reflect in all the decision-making methods. This is the reason behind China's widely acknowledged "administrative democracy". The values, which are internalized in the institutions, allow the various administrative institutional reforms and advancement of the reforms and opening-up across the board, even after 40 years of reform. How should we understand this peculiar phenomenon in the history of humanity's politics? The answer lies in the endogenic background of China's scholar-official tradition, which follows the people-oriented governance philosophy.

The value of institutions is not only reflected in the institutions themselves, but also instilled in the institutional matrix. In the party schools at all levels, officials are offered not only the knowledge on how to deal with a situation, but also on how to look at it. That is the input of worldview and epistemology. In these two senses, for Chinese officials, value takes a higher priority than responsibility, and often concerns the political order, especially the world order. This demonstrates the actual significance of the country's organizational and institutional system, and also formulates China's political system to not only be organizational, but also pragmatic and valuable to keep up to pace with the times.

In short, when looking at the attributes of national unity, political values, and political institutions, people probably acknowledge that the political development of contemporary China is a natural continuation of the genetic community of Chinese civilization. However, the vitality and legitimacy of China's political path and political institutions do not only stem from its historical and civilized genes, but also from institutional innovations, which are suitable for the national conditions and the real-time situations. We know that there are two biggest problems 
with traditional Chinese politics. One concerns the degree of organization, i.e., national governance capacity, and the other is about underrepresentation. The most unique feature of the political development of contemporary China is the national governance capacity guaranteed by the principle of democratic centralism. In the late Qing dynasty, the biggest challenge China faced was the ability to integrate the institutions, and its poor performance in doing so made it vulnerable to foreign powers. The principle of democratic centralism addresses the coordination between departments, central and local governments, and local governments themselves, thereby maximizing the national governance capacity. The competition among major powers today is fundamentally over institutions, and institutional competitiveness is reflected in governance capabilities, which include capabilities of institution integration, policy formulation, and policy implementation. In that sense, China's comparative advantages are quite evident, and that is one of the prominent reasons for it to become the world's second largest economy in such a short period of time.

In addition, the fundamental system of contemporary China is representative and consultative. Before 1949, a key problem in Chinese politics was insufficient representation. The people's congress system ensures the representation of local governments and ethnic groups, the political consultation system ensures the representation of different sectors and industries, and the "two sessions" addresses the tiao-kuai (branch and lump) system. In terms of participating in and discussing the government and political affairs, consultative democracy is embedded in the whole process. Consultative democracy is not solely possessed by the political consultation system; it is also a part of the people's congress system.

The institutional capacity, representativeness, and consultation manifested in the political development of contemporary China constitute the superiority and competitive advantage of China's political system. Political science should undertake comprehensive comparative research in that regard, as it is more valuable in comparative political research.

\section{The Continuity and Unity of China's Political Development Before and After the Reform and Opening-Up}

While observing the continuity of contemporary China as a civilized genetic community in its long-term history, the continuity and unity of the 70-year-old PRC appear to be more explicit and self-evident. Continuity and unity existed in history before and after the reform and opening-up: the post-reform period is not a denial of the pre-reform period and vice versa. In historical political science, the history before and after the reform and opening-up is on a continuous track. The institutional arrangements made in the pre-reform period identify the basic track and direction of institutional changes in the post-reform period, which, in turn, strengthen the institutional structure and basic system established during the 30 years before the reform and opening-up. 


\subsection{The Stability of the Constitutional Structure}

Mao Zedong's 'On the People's Democratic Dictatorship' and the 1954 Constitution based on it fundamentally establish the constitutional system of the PRC. Seen as returning to the 1954 Constitution, the current 1982 Constitution has been revised five times to improve or strengthen the basic provisions of the 1954 Constitution. There are two key points in China's constitutional system. One is the nature of the state, and the other is the organizational principle of the regime. No matter the manner in which China changes, they ensure that it falls within the established political direction and institutional matrix.

On the nature of the state, i.e., the state system in political science, Article 1 of the 1954 Constitution stipulates that "The People's Republic of China is a people's democratic country led by the working class and based on the alliance of workers and peasants". In the current Constitution, the first paragraph of Article 1 stipulates that "The People's Republic of China is a socialist state under the people's democratic dictatorship led by the working class and based on the alliance of workers and peasants"; the next paragraph stipulates that "The socialist system is the basic system of the People's Republic of China. The leadership of the Communist Party of China is the defining feature of socialism with Chinese characteristics. Disruption of the socialist system by any organization or individual is prohibited". Noticeably, while retaining provisions on the nature of the state, the current Constitution based on the 1982 Constitution has added provisions on how to defend the state system, that is, implementing the state system of the people's democratic dictatorship through the leadership of the CPC and the socialist system. Then, there arises the question of how to implement the socialist system, and that is a matter of the political system.

On the organizational principle of the regime, the first paragraph of Article 2 of the 1954 Constitution stipulates that "All power in the People's Republic of China belongs to the people. The National People's Congress and the local people's congresses at various levels are the organs through which the people exercise state power"; the second paragraph of Article 2 stipulates that "The National People's Congress, local people's congresses at all levels, and other state organs shall all apply democratic centralism". In other words, the organizational principle of democratic centralism is adopted in creating the people's congress and establishing the relationship between the people's congress and the government as well as the relationship between the central and local governments. The first paragraph of Article 3 of the current Constitution, which is based on the 1982 Constitution, stipulates that "The state organs of the People's Republic of China apply the principle of democratic centralism". The second, third, and fourth paragraphs of Article 3 provide for how to apply the principle of democratic centralism. "The National People's Congress and the local people's congresses at various levels are constituted through democratic elections. They are responsible to the people and subject to their supervision." "All administrative, supervisory, judicial, and procuratorial organs of the State are created by the people's congresses, to which they are responsible and by which they are overseen." "The division of functions and powers between the central and local state organs is guided by the principle of giving full scope to the initiative 
and enthusiasm of the local authorities under the unified leadership of the central authorities."

The state system and political system constitute the latitude and longitude of the constitutional system. From the 1954 Constitution to the current Constitution, the abstract expression of state-government has become more specific, which has ensured the continuity of China's political development after the reform and the opening-up. In a temporal sense, that should be attributed to the "four cardinal principles" proposed by Deng Xiaoping in 1979. As Mr. Deng understands it, reform and opening-up are inevitable, but there is uncertainty about how to reform and then open-up, and one can only cross the river by feeling the stones; however, it is certain that reform and opening-up can only be carried out within the established constitutional framework, i.e., in compliance with the "four cardinal principles". This means that while the things allowed are not entirely known, the prohibitions are clear. In that manner, one has to come up with new ideas while maintaining the bottom line.

\subsection{The Social Foundation of the Market Economy}

Under a stable constitutional structure, many policies or institutional arrangements in place had laid a foundation 30 years ago before the reform and opening-up started. The achievements that China has accomplished since the reform and opening-up are by no means rootless, nor are they some kind of random magic created by the market. It should be noted that several developing countries like India are more market-oriented than China, but they are far less capable in state governance. Amartya Sen, called the "conscience of economics", has the profoundest understanding in this regard. In his comparative study of India and China, he points out that "the 'magic' of China's market rests on the solid foundations of social changes that had occurred earlier, and India cannot simply hope for that magic, without making the enabling social changes - in education, health care, land reforms, etc., that facilitate the market functioning in the manner it has for China" (Sen and Drèze 1995). But it is also more than just those areas. As it is well known, the PRC managed to establish a modern industrial system in a backward agricultural country within a very short period of time. This process entails the most pivotal prerequisite for the development of the manufacturing industry and the formation of a manufacturing power after the reform and opening-up. In addition, the socioeconomic policies adopted in the 30 years before the reform and opening-up, regarding areas such as land and agriculture, education, women's liberation, and healthcare, were all conducive to the subsequent initiative.

1. Land system and agricultural policy. After the reform and opening-up, China's agricultural development and rapid modernization that relied on the collective ownership of land were directly related to the reform of the land system. Amartya Sen believes that, compared to India, the reason for the viability of the contracting system in China's rural areas is that there were no "social problems and economic inefficiencies of highly unequal land ownership." (Sen and Drèze 1995) Land opening caused a lot of social conflicts during the process of urbanization, and 
if China adopted a hereditary land system as several developing countries did, it would not be possible to accomplish China's modernization at the pace it has seen. Therefore, the land system reform, which has been criticized by theories, such as the new institutional economics, is precisely the instrumental prerequisite for the modernization of developing countries. A similar successful experience has been witnessed in South Korea and Taiwan. A majority of international authoritative research has found that land reform is a significant factor for the overall economic development of East Asia. Yet land reform alone is not enough in agriculture. Without the water conservancy projects in the 30 years before the reform and opening-up and the thousands of reservoirs, it would be unfeasible to address the agricultural issues that rely on natural harvests. This is something that other developing countries are incapable of, and it has effectively ensured China's grain harvest in recent decades.

2. Education and women's liberation. Through the implementation of mandatory education for all, the PRC greatly enhanced the quality and literacy of the people. At the same time, the country promoted the women's liberation movement to ensure equality between men and women, and girls enjoyed the same access to education as boys. According to the census data, the literacy rate of the 15-19 age group in 1982 was as high as 96 percent for men and 85 percent for women, compared to 66 percent and 43 percent in India during the same period, respectively (Sen and Drèze 1995). Without these efforts, there would be no high-quality labor force after the reform and opening-up, and there would be no superior female migrant workers, known as the "working women". A high-quality labor force guarantees the manpower that is required in a major manufacturing country. "Population" does not necessarily guarantee "manpower", it is education and women's liberation, which are the solution to transform the population into manpower for different factories.

3. Healthcare. "Barefoot doctors" (healthcare providers who receive basic medical training and work in rural villages in China) and the factual universal free medical care are the major elements of the fundamental guarantee for China's most successful comprehensive healthcare. How do we measure the success? In 1960, China had 150 deaths per 1000 newborns, which was certainly lower than India's 165; by 1981, the number had dropped to 37, the same as that of South Korea, while the number in India was 110 . The life expectancy of the Chinese born in 1960 was 47.1, and in 1981 it reached 67.7, which was higher than South Korea's 66 and approached the value of developed countries (Sen and Drèze 1995). China's achievements in healthcare have garnered massive worldwide attention and set a model for developing countries. This means that the level of health is not necessarily proportional to the level of the economy. The key is how much the government cares for the people and how effective the social policies are. While on one side the free compulsory education and women's liberation provided high-quality labor; on the other side, healthcare featuring "barefoot doctors" guaranteed a healthy labor force for the subsequent reform and opening-up.

It is evident that the eminent achievements accomplished by China since the reform and opening-up are the product of policy changes, but the social development 
implemented by China before the reform laid the foundation for the market economy. Therefore, Amartya Sen argues that, compared to India, the "eighties continued that progress and consolidated China's lead, but the relative standings had been decisively established before the Chinese reforms" (Sen and Drèze 1995). "We argue, in particular, that the accomplishments relating to education, health care, land reforms, and social change in the pre-reform period made significantly positive contributions to the achievements of the post-reform period. This is so in terms of their role not only in sustaining high life expectancy and related achievements, but also in providing firm support for economic expansion based on market reforms." (Sen and Drèze 1995). Amartya Sen's judgment is especially enlightening, and he also addresses the question of continuity before and after the reform in China. In terms of the degree of marketization, China is no higher than India and other developing countries, but how has it achieved so much of excellence in governance? The market economy is not created on the fly. It involves a government system and government functions at the upper level and social structure at the lower level. The function of the market can only play a role under the constraints of both government and social structures. Constrained by their knowledge and vision, people are utilized to uphold a country's prospects based on their market standards, which only indicates how ignorant and arrogant they are epistemologically.

\subsection{Institutional Innovation Continues and Strengthens the Constitutional Structure}

China's reform based on the market economy is conducted under a static constitutional structure. The social policies before the reform provided decisive benefits for reform and opening-up; and the institutional changes after the reform and opening-up strengthened the established constitutional structure in return, developing a more competitive institutional system in China. Specifically, the power relationships formed by institutional innovations centered around the fundamental political system, such as central-local, state-society, and government-market relationships, all possess the nature of democratic centralism. As a result, the democratic centralism regime appears continuous and strengthened, and the people's democratic state system consolidated.

China's reform began with the decentralization of powers, including administrative decentralization (i.e., delegation of powers), economic decentralization (i.e., change in the ownership of property rights), and fiscal decentralization (i.e., the shift from the overall rationing system to the tax-distribution system). Decentralization finally formed a new relationship between the central and local governments, which was called economic federalism. The central and local governments shared economic power, and the local governments gained greater autonomy in economy and governance. At the same time, the traditional political unity persisted, with the central government retaining absolute leadership over local political affairs, especially personnel matters. The political unity and economic federalism in the relationship between the central and local governments (Yang 2007) incorporated the relationship between centralization and decentralization. At the same time, they maintained 
the constitutional principle of the central government as the major source of power and effusively unleashed the vitality of local governments, hence, there exists the typical principle of democratic centralism in the relationship between the central and local governments as stipulated by the constitution (Yang 2018).

In the process of decentralization, changes in the economic pattern caused the transformation of the social structure, which inevitably generated new social organizations. The manner of dealing with the relationship between the state and society became a new conflict and focus. By and large, over the past several decades, China has imposed strict control over political, ethnic, legal, and religious organizations, because the "color revolutions" in many countries after the Cold War began with these types of social organizations; and it has provided the de facto freedom to cultural, economic, and environmental social organizations through the registration system and allowed them to be autonomous. Autonomy is also included in the autonomous community organizations such as village committees and neighborhood committees at the primary level. Classified management based on categories, namely control and deregulation, represents a de facto democratic centralist statesociety relationship, which is known as "state corporatism" in the Western politics (Yang 2018).

Both decentralization and market-oriented economic reform also fundamentally altered the integrated political-economic relationship under the planned economic system. Nonetheless, several institutional arrangements in the state power container still played an instrumental role, resulting in the political-economic relationship of what is called a "developmental state". In such developmental state, Chinese industrial policies such as the Five-Year Plan and the Ten-Year Plan reflect the national will, national direction, and the country's capability of institutional integration. This is the only way for late-developing countries to find their place among the developed ones. At the same time, the market economy has cultivated the autonomy of the interests of actors, and various economic interest groups are also competing to influence the decision-making process (Yang and Li 2008). In this manner, both the state and the market play a vital role, which can be seen as the concrete embodiment of democratic centralism in the government-market relationship (Yang 2018).

The relationships of power on various key dimensions derived from a stable constitutional structure are inseparable from the organizational principles of democratic centralism. Therefore, as a political system, democratic centralism lies at the core of the Chinese model and is the fundamental guarantee for the country's governance capabilities (Yang and Qiao 2015). In other words, this is the great cause of revival since the reform and opening-up took place under the constitutional structure in 1954 in China, and has yielded in the continuation and strengthening of the established constitutional structure.

China's constitutional structure can accommodate the two different economic forms of planned economy and socialist market economy. That makes us wonder: what is the relationship between politics and economy? Is it possible to address the political development of contemporary China in the dimension of the political-economic relationship? Why is the US Constitution, which was established in the era of slavery economy, capable of accommodating various economic systems-from agricultural capitalism to industrial capitalism to financial capitalism? As far as the 
factors affecting politics are concerned, the first one is an economic one, which is demonstrated by the interaction between political subjects that is initiated by the choice of people's interest; behind economy, there are the factors of social relationship and social structure; and behind social structure there is the factor of historical civilization genes. Therefore, to understand politics, one must consider the influence of deep-seated civilization genes, as well as the economic and social impacts. In fact, the analysis variables generated by these mutual influences have made it a challenge for us to distinguish between the political and the socioeconomical. Besides, to what extent can political power, as the sum and result of the interaction of economic power, cultural power, and military power, remain stable and resilient once it is created? A singular or simple factor would always fail to answer this question suitably. It can only be answered through in-depth historical research involving various case studies. That is probably a mission that could be appointed to historical political science.

\section{The Mutual Significance of Historical Political Science and the Political Development of Contemporary China}

As a significant country in terms of its history and size, China should not merely serve as a testing ground for foreign theories. It should develop its own theory and establish an autonomous Chinese social science discourse system. To achieve that goal, breakthroughs should be first made in research methods and approaches, which could be followed by novel concepts, new categories, and fresh expressions. Historical political science is a concept and approach tailored for Chinese political studies.

\subsection{The Significance of Historical Political Science for Chinese Political Studies}

Chinese politics is a holistic concept. In the structural sense, it should at least include: (1) how China transpired-this is the agenda of state-building; (2) how China is organized-this is the agenda of polity; (3) how China works-this is the agenda of the political process. "History" is an indispensable element and perspective in all of three respects. That is to say, each agenda is related to a historical issue, and the issues can only be comprehended through a historical perspective. At the level of state-building, modern China is in fact a continuation of the gene community of Chinese civilization; at the level of polity, the key elements of China's political system, such as the organization department and the supervision system, are new expressions of historical continuity. The remarkable changes that have materialized during the 70 years since the inception of the PRC are internal institutional changes under mutual reinforcement. Even China's political process, such as the legislative and the decision-making process at different levels, is historical with respect to every part and micro-mechanism. For example, historical continuity is maintained in relations through dependence on the approach. In foreign relations, from the five principles of "peaceful coexistence" in Mao Zedong's time, to "peace and development", "peaceful rise", and "a community with a shared future for mankind" 
since the reform and opening-up, the essence of Chinese culture-charmony" and a "world view"-is adopted everywhere. Historical political Science is the only approach available to address these distinguished agendas in institutional changes.

What kind of human nature do the "Chinese" have in the structure? Clearly, it is not right to simply analyze the political behavior of the Chinese based on the idea of rational man in the individualist culture. Rational man in the individualistic culture is not equivalent to man in the ethics-centered ancient times, "man of different classes", or the Chinese, who are impossible to characterize till now. Chinese rationality must be the product of collectivism culture. The famous British political scientist Finer says, "This [China's] polity is completely foreign to anything in the Western tradition since the Greeks. Indeed, it is antithetical. This polity, the prevalent belief systems, and the social structure all came to support one another as never since the high days of Mesopotamian and Egyptian eras and emphatically as never in the West, hence the stability and duration of the Chinese social and political system and the restlessness and liability of the West. Where the latter reposed on freely acting and personally responsible individuals, China reposed on collectivities, where all were responsible for the misdeeds of one another." The Western tradition embodied the notion of human equality before the law and in the sight of God, whereas the Chinese state started from the exactly opposite viewpoint on hierarchical relationships, but in China's political system, there was present "an organic society where all these unequals were induced to cohere into a harmonious whole" (Finer 1999). Indeed, in such a hierarchical society, "state" and "family" were always integrated into the system. As Mr. Li Zehou puts it, as opposed to the Western individualistic culture, the Chinese culture is "relationalism", which is based on the ethics observed in families, and the state is an enlarged version of the family. Therefore, as David Hall and Roger Ames, the American professors of Chinese philosophy, state, "In Western tradition, independent individuals occupy an important position. It would be futile to find such dominant ideas, which western intellectuals espouse, within the confines of Chinese tradition. More importantly, the values, behaviors and systems that express these ideological components also do not exist in Chinese tradition" (Hall and Ames 1999). They also identify that "politics and economy are cultural expressions, and their effectiveness must be assessed together with other cultural values. In particular, we believe that liberal, individualistic and rights-based democracy, as well as free enterprise capitalism, are concrete products of the historical development of western modernity. Therefore, any attempt to make these things universal in various cultures may be foolish". "One obvious implication is that moving all these things that work in China will dramatically change China's identity and, in effect, transform the whole of Chinese society into a terminal of foreign historical narratives." (Hall and Ames 1999).

The American scholars are right that modernity means more similarities and even resemblance among the political forms, such as party politics and parliamentary politics. But why do similar institutional designs bring different results? The factor of social structure must be decisive. The differences in human nature and people's behavior in various social structures lead to different outcomes in the same system. This in itself is a failure of "political science" based on the rational man hypothesis, and the alternative paradigm of interpretation should be historical political science. 
In other words, historical political science is not only structural, but also behavioral. It analyzes people's value orientation and interest calculation and firmly believes in the irreplaceable explanatory power of social structure.

All this is because historical political science is not only epistemological and methodological, but also, above all, ontological in nature. Historical political science constitutes an integral part of the Chinese development. This is why we say that it has an explicit value and is even tailored for the Chinese political studies. But this does not indicate that historical political science can only be utilized for the Chinese political studies. In my opinion, where there is a civilization body, such as Christian civilization or Islamic civilization, historical political science can be applied to assess the political development anywhere. Pertinently, as China is the only substantial civilization in the world that has not been interrupted for over thousands of years, its "history" appears to be more ontological in nature.

\subsection{The Significance of Chinese Political Studies for Historical Political Science}

As is the case with any other research paradigm, historical political science relies on certain case studies to maintain its vitality and verify its explanatory power. In other words, modern social sciences basically involve case studies, which means that they are local knowledge and that political scientists would naturally study the history and reality they are familiar with first. For example, the legitimacy of bureaucracy proposed by Max Weber targets the history and politics of Germany, and Lipset generalizes Weber's legitimacy as electoral democracy based on the American and British politics. Some even begin the approaches and paradigms with their familiar history. Douglas North's new institutional economics (state theory, property rights theory, and ideological theory) is also based on the historical experience of several European countries. In fact, by the virtue of comparative history, as far as bureaucracy and state theory are concerned, China is a more valuable case than Germany and Britain, but it is impossible for scientists to acknowledge it that way as they are not familiar with the Chinese history. Therefore, the Chinese have received exotic theories to explain China, which has been made into a testing ground for these westcentered theories.

With social science training and methodological consciousness, Chinese political scientists should use the history and reality they are familiar with to give life to the appropriate methodology and approach. Revolution-oriented political science has its special political mission and specific analytical value, and political science based on the rational man hypothesis is actually being "transgenic" to build an individualistic society. Therefore, it is urgent to theorize the historical political science that explains Chinese politics and endows research value to it. The infinite power of historical political science will be exploited if Chinese politics is taken as a case study. At the source, pre-Qin politics has the innate secularization and the bureaucratic modernity; during the course of evolution, the two-thousand-year history is the initial dependence of key nodes upon the approach; and the remarkable changes of the past century since the end of late Qing dynasty are still materializing in the sense of historical continuity. No country in the world has such powerful historical 
civilization genes in its political scenario, which means that China's future political development still pertains to the Chinese history. The nature of the Chinese history will not be changed by external impacts or "modernization". That would be determined by the characteristics of the Chinese civilization, i.e., a continuum of civilization or, the "China basal body theory" proposed by Kozo Mizoguchi. In that manner, we can understand the last sentence of the book by Philip Kuhn, “... the Chinese constitutional agenda will still be addressed on China's terms, not on ours" (Kuhn 2002).

If history is deemed as a "religion" for the Chinese and historical analysis is the "original mission" and constant pursuit of the Chinese political scientists, a community for historical political science is bound to be formed. We can expect the constructive contribution of historical political science to China's autonomous political discourse system. The comprehensive case study of China's political development will also vitalize academic research and even discipline construction in historical political science.

\section{Declarations}

Conflict of interest All Authors declared that they have no conflict of interest.

Ethical statement I certify that this manuscript is original and has not been published and will not be submitted elsewhere for publication.

Open Access This article is licensed under a Creative Commons Attribution 4.0 International License, which permits use, sharing, adaptation, distribution and reproduction in any medium or format, as long as you give appropriate credit to the original author(s) and the source, provide a link to the Creative Commons licence, and indicate if changes were made. The images or other third party material in this article are included in the article's Creative Commons licence, unless indicated otherwise in a credit line to the material. If material is not included in the article's Creative Commons licence and your intended use is not permitted by statutory regulation or exceeds the permitted use, you will need to obtain permission directly from the copyright holder. To view a copy of this licence, visit http://creativecommons.org/licen ses/by/4.0/.

\section{References}

Almond, Gabriel A., and James S. Coleman. 1960. The Politics of the Developing Areas. Princeton University Press.

Carothers, Thomas. 2015. The End of the Transition Paradigm, in Yang Guangbin ed., Review of Comparative Politics Issue 1.

Chen, Huanzhang. 2009. The Economic Principles of Confucius and His School. Central Compilation and Translation Press.

Dahl, Robert. 1998. On Democracy. Yale University Press.

Durant, Will. 1963. The Story of Civilization: Our Oriental Heritage. Simon and Schuster.

Eckstein, Harry. 1998. Unfinished Business: Reflection on the Scope of Comparative Politics. Comparative Political Studies 31 (4): 505-534.

Finer, S.E. 1999. The History of Government from the Earliest Times: Ancient Monarchies and Empires. Oxford University Press.

Fukuyama, Francis. 1992. The End of History and the Last Man. Free Press.

Habermas, Jürgen. 1973. Theory and Practice. Beacon Press. 
Hall, David, and Roger Ames. 1999. The Democracy of the Dead: Dewey, Confucius, and the Hope for Democracy in China. Open Court.

Hobbes, Thomas. 1688/1994. Leviathan. Hackett Publishing Co, Inc.

Huang, Minghan, and Yanjie Huang. 2013. The Vicissitudes of "China Watch" in the West. Lianhe Zaobao (8 April 2013).

Kuhn, Philip. 2002. Origins of the Modern Chinese State. Stanford University Press.

Ma, Rong. 2011. Does China Face a Risk of Division in the 21st Century? Leaders Issue 38 and 39.

Mao, Zedong. 1991. Selected Works of Mao Zedong, vol. 2. People's Publishing House.

Mizoguchi, Kozo. 2011. China as Method.

Rothbard, Murray. 2006. Economic Thought Before Adam Smith. Ludwig von Mises Institute.

Sen, Amartya, and Jean Drèze. 1995. India: Economic Development and Social Opportunity. Oxford University Press.

Sun, Yat-sen. 2011. The Complete Works of Sun Yat-sen, vol. II. Zhonghua Book Company.

Tilly, Charles. 2006. Why and How History Matters. In The Oxford Handbook of Contextual Analysis, ed. Robert E. Goodin and Charles Tilly. New York: Oxford University Press.

Toynbee, Arnold, and Daisaku Ikeda. 1976. Choose Life: A Dialogue. Oxford University Press.

Waltz, Kenneth N. 2008. Realism and International Politics. Routledge.

Weber, Max. 1921/1978. Economy and Society: An Outline of Interpretive Sociology. University of California Press.

Xi, Jinping. 2014. The Governance of China. Foreign Languages Press.

Xie, Maosong. 2019. Rebuilding the Practice of Politics: The Absence of Practical Wisdom in Contemporary Chinese Politics. Dongfang Journal Spring Issue 3.

Xu, Yong. 2018a. Rights from Ancestors: Ontological Construction Originated from Blood Reason. Social Sciences in China Issue 1.

Xu, Yong. 2018b. Review of and Prospect for the Survey of Chinese Rural Areas from the Perspective of Historical Continuity: Revisiting the Research on Chinese Rural Areas at a New Historical Point. Jinlin University Journal Social Sciences Edition Issue 3.

Yang, Guangbin. 2007. A New Probe into the Relationship between the Central and Local Governments in the Period of China's Economic Transition: Theory, Reality and Policy. Academia Bimestrie Issue 1.

Yang, Guangbin. 2011. The Path of Institutional Changes and Its Value in Social Science: Society-Centrism, State-Centrism, and Party-Centrism and States and Institutions in Political Changes. Central Compilation and Translation Press.

Yang, Gunagbin. 2016a. The Basal Body of Chinese Civilization: An Epistemology to Understand the Future of Chinese Politics. People's Tribune Issue 15.

Yang, Guangbin. 2016b. Comparative Politics: Theory and Method. Peking University Press.

Yang, Guangbin. 2018. Chinese Political Epistemology. China Social Science Press.

Yang, Guangbin, and Yuejun Li. 2008. Interest Groups and How They Are Governed in China's Political Process. Academia Bimestrie Issue 2.

Yang, Guangbin, and Zheqing Qiao. 2015. On the Political System of Democratic Centralism as the Chinese Model. CASS Journal of Political Science Issue 6.

Guangbin Yang Ph.D., distinguished professor of political science and dean of School of International Studies at Renmin University of China, Changjiang Scholor distinguished professor, founder of Chinese Political Science, and World Politics Studies, vice president of Chinese Political Science Association. His areas of study include political science theories and methods, comparative politics, world politics, contemporary Chinese politics and government, Chinese political economy and international relations. He has authored and edited more than 10 books and published more than 100 papers in the above areas. 